\title{
HUBUNGAN ASUPAN ZAT GIZI, AKTIVITAS FISIK, DAN PERSENTASE LEMAK TUBUH DENGAN GANGGUAN SIKLUS MENSTRUASI PADA PENARI
}

\author{
Pristina Adi Rachmawati, Etisa Adi Murbawani*) \\ Program Studi Ilmu Gizi Fakultas Kedokteran Universitas Diponegoro \\ J1.Dr.Sutomo No.18, Semarang, Telp (024) 8453708, Email : gizifk@ undip.ac.id
}

\begin{abstract}
Background : Dancing has been classified in high physical activity level. Dancer tend to restrict food intake to achieve a slim body shape. The lack of nutrients intake with strenuous physical activity for a certain periods resulted in disruption of menstrual cycle.

Objective : To examined the association between nutrients intake, physical activity, and body fat percentage with menstrual cycle disorders in dancer.

Methods : Cross sectional study at 62 dancers selected by simple random sampling. Nutrients intake were obtained from Food Frequency Questionnaire (FFQ) and analyzed with Nutrisurvey program. Physical activity were measured by International Physical Activity Questionnaire Adolescent (IPAQ). Body fat percentage was measured by Bioelectrical Impedance Analysis (BIA). Menstrual cycle disorders were assessed by questionnaire. Bivariate analysis used Chi Square test.

Results : There were 51,6\% dancers suffered from menstrual cycle disorders. Energy intake at 46,8\% dancers were classified as moderate deficit. Protein (32,3\%) and carbohydrate (51,6\%) intake were classified as mild deficit. Fat intake of 37,1\% dancers were classified as severe deficit. Most of dancers had high physical activity level (91,9\%) and normal body fat percentage (87.1\%). There were correlation between energy intake, carbohydrate intake, fat intake, and physical activity with menstrual cycle disorders $(p<0,05)$. There were no correlation between protein intake and body fat percentage with menstrual cycle disorders $(p>0,05)$.

Conclusion : Energy intake, carbohydrate intake, fat intake, and physical activity associated with menstrual cycle disorders.

Keywords : nutrients intake; physical activity; body fat percentage; menstrual cycle disorders; dancer
\end{abstract}

\section{ABSTRAK}

Latar Belakang : Menari termasuk dalam kategori aktivitas fisik yang berat. Penari cenderung membatasi asupan makan untuk mencapai bentuk tubuh yang ramping. Kurangnya asupan zat gizi disertai aktivitas fisik yang berat dalam jangka waktu tertentu mengakibatkan gangguan siklus menstruasi.

Tujuan : Mengetahui hubungan asupan zat gizi, aktivitas fisik, persentase lemak tubuh dengan gangguan siklus menstruasi pada penari.

Metode : Desain penelitian cross sectional dengan 62 penari dipilih secara simple ramdom sampling. Asupan zat gizi diperoleh melalui Food Frequency Questionaire (FFQ) dan dianalisis menggunakan program Nutrisurvey. Aktivitas fisik diukur menggunakan International Physical Activity Questionnaire Adolescent (IPAQ). Persentase lemak tubuh diukur menggunakan Bioelectrical Impedance Analysis (BIA). Gangguan siklus menstruasi diperoleh melalui kuesioner. Analisis bivariat menggunakan uji Chi Square.

Hasil : Sebanyak 51,6\% penari mengalami gangguan siklus menstruasi. Asupan energi pada 46,8\% penari tergolong defisit tingkat sedang. Asupan protein (32,3\%) dan asupan karbohidrat (51,6\%) tergolong defisit tingkat ringan. Asupan lemak 37,1\% penari tergolong defisit tingkat berat. Sebagian besar penari memiliki aktivitas fisik yang berat (91,9\%) dan persentase lemak tubuh yang normal (87,1\%). Terdapat hubungan antara asupan energi, karbohidrat, lemak dan aktivitas fisik dengan gangguan siklus menstruasi ( $p<0,05)$. Tidak ada hubungan antara asupan protein dan persentase lemak tubuh dengan gangguan siklus menstruasi ( $p>0,05)$.

Simpulan : Asupan energi, karbohidrat, lemak, dan aktivitas fisik berhubungan dengan gangguan siklus menstruasi.

Kata Kunci : Asupan zat gizi; aktivitas fisik; persentase lemak tubuh; gangguan siklus menstruasi; penari

\section{PENDAHULUAN}

Menari adalah sebuah ungkapan gerak emosional dengan pola gerak tubuh yang ekspresif dan komunikatif. Menari sebanding dengan olahraga yang tergolong dalam aktivitas fisik yang berat dilihat dari segi fisik, ketangkasan, dan psikologis. $^{1}$ Penari maupun atlet selalu meningkatkan kualitas dengan berlatih berulangulang agar dapat tampil maksimal dalam sebuah pertunjukan. Hal ini menuntut penari untuk selalu dalam kondisi yang prima. Kondisi tersebut dipengaruhi oleh $40 \%$ faktor genetik dan $60 \%$ dari latihan fisik secara teratur dan asupan makan yang cukup. $^{2}$

\footnotetext{
${ }^{*}$ Penulis Penanggungjawab
} 
Penari selalu memperhatikan bentuk tubuh mereka agar dapat lebih memaksimalkan pertunjukan. Bentuk tubuh yang lebih ramping dianggap dapat mempermudah dalam bergerak. ${ }^{3,4}$ Penari cenderung membatasi asupan makan agar dapat mencapai bentuk tubuh tersebut. Sebuah studi yang dilakukan oleh Frusztajer, ditemukan $70 \%$ dari penari memiliki rata-rata tingkat asupan zat gizi sehari-hari di bawah $85 \%$ Angka Kecukupan Gizi. ${ }^{5}$ Asupan zat gizi berhubungan positif dengan persentase lemak tubuh. Persentase lemak tubuh akan semakin rendah seiring dengan kurangnya asupan zat gizi dan tingginya pengeluaran energi melalui aktivitas fisik. $^{6}$ Kurangnya asupan zat gizi disertai latihan fisik dengan intensitas yang tinggi dalam jangka waktu tertentu dapat menimbulkan perubahan fisiologi salah satunya pada sistem menstruasi yang menyebabkan adanya gangguan menstruasi pada penari. ${ }^{4,7,8}$

Gangguan menstruasi merupakan masalah fisik atau mental yang mempengaruhi siklus menstruasi, menyebabkan nyeri, perdarahan yang tidak biasa yaitu lebih banyak (hipermenore) atau lebih sedikit (hipomenore), terlambatnya menarche (pertama kali mengalami menstruasi) atau hilangnya siklus menstruasi tertentu (amenore). ${ }^{7}$ Gangguan menstruasi merupakan indikator penting yang menunjukkan adanya gangguan fungsi sistem reproduksi yang berhubungan dengan peningkatan risiko berbagai penyakit seperti kanker rahim dan payudara, infertilitas, serta fracture tulang. ${ }^{9}$ Gangguan menstruasi disebabkan oleh beberapa faktor diantaranya adanya gangguan makan, kurangnya ketersediaan energi, penurunan berat badan, aktivitas fisik yang berlebihan, berat badan berlebih, dan faktor stress. Hal ini mengakibatkan adanya penekanan hipotalamus pituitari ovarium yang disebut dengan Functional hypothalamic amenorrhea, ditandai dengan penekanan Gonadotropin Releasing Hormon (GnRH) yang mempengaruhi pelepasan Luteinizing Hormon (LH) dan Follicle Stimulating Hormon (FSH), hormon estrogen dan progesteron. Penurunan frekuensi pelepasan LH dan FSH dari kelenjar pituitari mengakibatkan adanya penekanan pada ovarium sehingga menyebabkan terjadinya menarche yang tertunda dan gangguan siklus menstruasi. ${ }^{7,10}$ Siklus menstruasi dikatakan normal jika jarak antara hari pertama keluarnya darah menstruasi dengan hari pertama terjadinya menstruasi berikutnya memiliki selang waktu 2135 hari. $^{11}$

Penelitian yang dilakukan oleh Frisch et $a l$, ditemukan tingginya insiden amenore primer, amenore sekunder, siklus menstruasi tidak teratur dan tertundanya menarche pada 89 penari balet, kejadian ini berhubungan dengan tingkat kerampingan bentuk tubuh. ${ }^{4}$ Sabbour dan El dalam penelitiannya menemukan penari dengan gangguan siklus menstruasi oligomenore memiliki persentase lemak tubuh lebih rendah dibandingkan penari dengan siklus menstruasi normal. ${ }^{12}$ American College of Sport Medicine (ACSM) mendapatkan tingginya prevalensi amenore sekunder pada $69 \%$ penari. ${ }^{13}$ Penelitian lain menyebutkan bahwa kelainan sistem reproduksi termasuk gangguan siklus menstruasi dialami oleh 6-79\% perempuan yang terlibat dalam kegiatan dengan aktivitas berat seperti olahragawan, penari, dan pesenam. ${ }^{14}$

Di Indonesia belum banyak ditemukan penelitian mengenai gangguan siklus menstruasi pada penari. Tingginya angka kejadian gangguan siklus menstruasi pada penari yang telah dilakukan pada penelitian sebelumnya mendorong untuk dilakukan penelitian ini.

\section{METODE}

Penelitian ini merupakan penelitian deskriptif analitik dengan pendekatan cross sectional. Penelitian ini termasuk dalam ruang lingkup ilmu gizi masyarakat dikaitkan dengan ilmu kebidanan (ginekologi). Penelitian dilakukan di Program Studi Seni Tari Universitas Negeri Semarang (UNNES).

Populasi dalam penelitian ini adalah semua mahasiswi Program Studi Pendidikan Seni Tari UNNES. Kriteria inklusi sampel dalam penelitian ini yaitu berusia 19-22 tahun, tidak dalam kondisi sakit, tidak merokok, tidak mengkonsumsi alkohol, tidak mengkonsumsi obat hormon seperti norethinodrel, pil $\mathrm{KB}$, dan bersedia mengisi informed consent. Berdasarkan perhitungan besar sampel menggunakan rumus analitik korelatif dibutuhkan sampel minimal 56 orang. Pemilihan sampel menggunakan teknik simple random sampling pada 153 penari. Didapatkan 70 penari yang bersedia menjadi responden, tetapi berdasarkan kriteria inklusi tersebut dilakukan drop out terhadap 8 responden dikarenakan sedang mengkonsumsi obat hormon, merokok, dan mengkonsumsi alkohol sehingga didapatkan 62 orang sebagai sampel dalam penelitian ini.

Variabel bebas dalam penelitian ini yaitu asupan zat gizi makro, aktivitas fisik, dan persentase lemak tubuh. Variabel terikatnya adalah gangguan siklus menstruasi. Data yang diambil dalam penelitian ini antara lain data identitas sampel, data antropometri meliputi tinggi badan, berat badan dan persentase lemak tubuh, data 
asupan zat gizi meliputi asupan energi, protein, lemak, dan karbohidrat, data aktivitas fisik, serta data siklus menstruasi. Pengambilan sampel diawali dengan melakukan pengumpulan data meliputi identitas sampel, pengukuran tinggi badan menggunakan microtoise dengan ketelitian $0,1 \mathrm{~cm}$, dan pengukuran berat badan dengan menggunakan timbangan injak digital dengan ketelitian $0,1 \mathrm{~kg}$.

Asupan zat gizi meliputi asupan energi, protein, lemak, dan karbohidrat didefinisikan sebagai jumlah asupan energi, protein, lemak, dan karbohidrat yang berasal dari makanan dan minuman yang dikomsumsi sehari-hari diperoleh melalui wawancara langsung menggunakan Food Frequency Questionaire (FFQ). Data yang diperoleh akan dikonversikan ke dalam satuan gram dan dihitung besar energi, protein, lemak, dan karbohidrat menggunakan program nutrisurvey kemudian dibandingkan dengan Angka Kecukupan Gizi (AKG) individu. Depkes mengkategorikan tingkat kecukupan asupan zat gizi dalam 5 kelompok yaitu defisit tingkat berat $(<70 \%)$, defisit tingkat sedang (70-79\%), defisit tingkat ringan $(80-89 \%)$, normal $(90-119 \%)$, dan di atas kecukupan $(\geq 120 \%){ }^{15}$

Aktivitas fisik diukur menggunakan International Physical Activity Questionnaire Adolescent (IPAQ) untuk mengetahui besar energi yang dikeluarkan subjek dalam berkegiatan selama 7 hari terakhir kemudian dilakukan scoring dan dihitung menggunakan rumus yang sudah ditentukan dengan satuan MET-menit/minggu. Hasil perhitungan dikategorikan menjadi aktivitas ringan (<600 MET-menit/minggu), aktivitas sedang (600-2999 MET-menit/minggu), dan aktivitas berat (>2999 MET-menit/minggu). ${ }^{16}$

Persentase lemak tubuh didefinisikan sebagai perbandingan total lemak tubuh dengan berat badan yang diukur menggunakan Bioelectrical Impedance Analysis (BIA) dengan ketelitian $0,1 \%$. Hasil ukur dinyatakan dalam bentuk persentase $(\%)$ yang dikategorikan menjadi Underfat $(<21 \%)$, normal $(21-32 \%)$, Overfat (33$39 \%)$, dan obesitas (>39\%). ${ }^{17}$

Gangguan siklus menstruasi didefinisikan sebagai gangguan siklus menstruasi yang dialami dalam 12 bulan terakhir, ditandai dengan panjang jarak antara hari pertama siklus menstruasi dengan hari pertama siklus menstruasi berikutnya $<21$ hari atau $>35$ hari. Data kejadian gangguan siklus menstruasi ini diperoleh dengan recall menggunakan kuesioner. Hasil recall dikategorikan menjadi 4 yaitu, polimenore (siklus menstruasi <21 hari), normal (siklus menstruasi 21-35 hari), oligomenore (siklus menstruasi $>35$ hari), dan amenore (siklus $>3$ bulan). ${ }^{11,18}$

Analisis univariat dilakukan untuk mendeskripsikan masing-masing variabel. Analisis bivariat digunakan untuk mengetahui hubungan masing-masing variabel bebas dengan gangguan siklus menstruasi menggunakan uji Chi Square.

\section{HASIL PENELITIAN \\ Karakteristik Sujek}

Penelitian ini dilakukan di Universitas Negeri Semarang (UNNES) pada bulan September 2014. Subjek penelitian merupakan mahasiswi tari semester III-IX yang berusia 19-22 tahun berjumlah 62 orang.

Tabel 1. Nilai Minimum, Maksimum, Rerata, dan Standar Deviasi Karakteristik Subjek

\begin{tabular}{lccl}
\hline \multirow{2}{*}{ Karakteristik subjek } & \multicolumn{3}{c}{$\mathbf{n = 6 2}$} \\
\cline { 2 - 4 } & Minimum & Maximum & Rerata \pm SD \\
\hline Usia responden (tahun) & 19 & 22 & $19,61 \pm 0,837$ \\
Usia menarche (tahun) & 11 & 16 & $12,53 \pm 1,112$ \\
Indeks masa tubuh (kg/m ${ }^{2}$ ) & 15,8 & 27,9 & $20,22 \pm 2,316$ \\
Persentase lemak tubuh (\%) & 14,9 & 38,6 & $26,61 \pm 4,292$ \\
Aktivitas fisik (MET-menit/minggu) & 2225,0 & 11679,0 & $6263,54 \pm 2577,190$ \\
Asupan energi (Kkal) & 1150,70 & 1923,80 & $1483,48 \pm 167,222$ \\
Asupan protein (gram) & 29,80 & 56,00 & $42,00 \pm 5,452$ \\
Asupan lemak (gram) & 36,40 & 76,80 & $50,29 \pm 8,427$ \\
Asupan karbohidrat (gram) & 164,60 & 291,70 & $220,52 \pm 27,336$ \\
\hline
\end{tabular}

Berdasarkan Tabel 1, subjek memiliki rentang usia menarche yang normal yaitu 11-16 tahun dengan sebagian besar subjek mengalami menarche pada usia 12 tahun. Subjek memiliki rerata indeks masa tubuh (IMT) dan persentase lemak tubuh $20,22 \pm 2,31 \mathrm{~kg} / \mathrm{m}^{2}$ dan $26,61 \pm 4,29 \%$. Aktivitas fisik subjek tergolong berat dengan rerata
$6263,54 \pm 2577,19$ MET-menit/minggu. Rerata asupan energi seluruh subjek adalah $1483,48 \pm 167,22$ Kkal dengan nilai terendah 1150,70 Kkal dan nilai tertinggi 1923,80 Kkal. Rerata asupan protein seluruh subjek adalah $42,00 \pm 5,45$ gram dengan nilai terendah 29,80 gram dan nilai tertinggi 56,00 gram. Rerata asupan 
lemak seluruh subjek adalah 50,29 $\pm 8,42$ gram dengan nilai terendah 36,40 gram dan nilai tertinggi 76,80 gram. Rerata asupan karbohidrat seluruh subjek adalah 220,52 $\pm 27,33$ gram dengan nilai terendah 164,60 gram dan nilai tertinggi 291,70 gram.

\section{Status Gizi}

Status gizi pada subjek berdasarkan IMT pada penelitian ini beragam. Sebagian besar subjek memiliki status gizi normal $(71,0 \%)$ dan hanya 2 subjek $(3,2 \%)$ dengan status gizi obesitas I.

Tabel 2. Distribusi Frekuensi Status Gizi

\begin{tabular}{lcc}
\hline & Kategori & Frekuensi \\
\cline { 2 - 3 } & $(\mathbf{n})$ & $(\boldsymbol{\%})$ \\
\hline Underweight & 12 & 19,4 \\
Normal & 44 & 71,0 \\
Overweight & 4 & 6,5 \\
Obes I & 2 & 3,2 \\
\hline
\end{tabular}

\section{Asupan Zat Gizi}

Asupan zat gizi meliputi energi, protein, lemak, karbohidrat. Asupan energi yang normal hanya ditemukan pada 1 subjek $(1,6 \%)$, selebihnya subjek memiliki asupan energi kategori defisit tingkat ringan hingga berat. Asupan protein sebagian besar $(40,3 \%)$ subjek adalah normal dan 5 subjek $(8,1 \%)$ dengan kategori defisit tingkat berat. Asupan lemak 37,1\% subjek tergolong defisit tingkat berat, dan hanya 9 subjek (14,5\%) yang tergolong normal. Asupan karbohidrat sebagian besar subjek $(51,6 \%)$ tergolong defisit tingkat ringan dan hanya 4 subjek $(6,5 \%)$ yang tergolong normal.

Tabel 3. Distribusi Frekuensi Asupan Energi, Protein, Lemak, dan Karbohidrat

\begin{tabular}{lrr}
\hline \multicolumn{1}{c}{ Kategori } & Frekuensi & $(\mathbf{n})$ \\
\cline { 2 - 3 } & & \\
\hline Asupan Energi & 13 & 21,0 \\
Defisit tingkat berat & 29 & 46,8 \\
Defisit tingkat sedang & 19 & 30,6 \\
Defisit tingkat ringan & 1 & 1,6 \\
Normal & & \\
\hline Asupan Protein & 5 & 8,1 \\
Defisit tingkat berat & 12 & 19,4 \\
Defisit tingkat sedang & 20 & 32,3 \\
Defisit tingkat ringan & 25 & 40,3 \\
Normal & & \\
\hline Asupan Lemak & 23 & 37,1 \\
Defisit tingkat berat & 15 & 24,2 \\
Defisit tingkat sedang & 15 & 24,2 \\
Defisit tingkat ringan & 9 & 14,5 \\
Normal & & 9,7 \\
\hline Asupan Karbohidrat & 6 & 51,6 \\
Defisit tingkat berat & 20 & 6,5 \\
Defisit tingkat sedang & 32 & \\
Defisit tingkat ringan & 4 & \\
Normal & & \\
\hline
\end{tabular}

\section{Aktivitas Fisik}

Aktivitas fisik subjek dalam penelitian ini sebanyak 57 subjek $(91,9 \%)$ tergolong berat. Aktivitas fisik kategori sedang hanya ditemukan pada 5 subjek $(8,1 \%)$. Tidak ditemukan subjek dengan aktivitas fisik kategori ringan.

\section{Persentase Lemak Tubuh}

Persentase lemak tubuh subjek penelitian ini sebagian besar tergolong normal yaitu sebanyak 54 subjek $(87,1 \%)$. Sebanyak 5 subjek $(8,1 \%)$ termasuk dalam kategori underfat. Persentase lemak tubuh dengan kategori overfat hanya ditemukan pada 3 subjek $(4,8 \%)$. 


\section{Gangguan Siklus Menstruasi}

Selama 12 bulan terakhir, dari total 62 subjek terdapat 32 subjek $(51,6 \%)$ mengalami gangguan siklus menstruasi. Berdasarkan Tabel 4, dapat dilihat gangguan siklus menstruasi yang dialami beragam.

Tabel 4. Kejadian Gangguan Siklus Menstruasi Selama 12 Bulan Terakhir

\begin{tabular}{|c|c|c|c|c|}
\hline \multirow{2}{*}{ Karateristik } & \multirow{2}{*}{\multicolumn{2}{|c|}{ Kategori }} & \multicolumn{2}{|c|}{ Frekuensi } \\
\hline & & & (n) & $(\%)$ \\
\hline \multirow{9}{*}{$\begin{array}{l}\text { Kejadian } \\
\text { gangguan siklus } \\
\text { menstruasi }\end{array}$} & Normal & & 30 & 48,4 \\
\hline & $\begin{array}{l}\text { Gangguan siklus } \\
\text { menstruasi }\end{array}$ & & 32 & 51,6 \\
\hline & & Polimenore & 8 & 12,9 \\
\hline & & Oligomenore & 10 & 16,1 \\
\hline & & Amenore & 1 & 1,6 \\
\hline & & Polimenore + oligomenore & 9 & 14,5 \\
\hline & & Polimenore + amenore & 1 & 1,6 \\
\hline & & Oligomenore + amenore & 1 & 1,6 \\
\hline & & Polimenore + oligomenore + amenore & 2 & 3,2 \\
\hline
\end{tabular}

Subjek dengan status gizi normal $(52,3 \%)$ mengalami gangguan siklus menstruasi. Subjek dengan underfat (40\%) dan overfat (100\%) mengalami gangguan siklus menstruasi. Subjek dengan aktivitas fisik berat $(56,1 \%)$ mengalami gangguan siklus menstruasi. Subjek dengan defisit tingkat berat asupan energi (100\%), asupan lemak $(78,3 \%)$, dan asupan karbohidrat (100\%) mengalami gangguan siklus menstruasi. Subjek dengan asupan protein normal (64\%) mengalami gangguan siklus menstruasi.

Tabel 5. Distribusi Frekuensi kejadian Gangguan Siklus Menstruasi

\begin{tabular}{|c|c|c|c|}
\hline \multirow{3}{*}{ Karakteristik dan Kategori } & \multicolumn{2}{|c|}{ Kejadian Gangguan Sikus Menstruasi } & \multirow{2}{*}{ Total } \\
\hline & Gangguan & Normal & \\
\hline & $\mathbf{n}(\%)$ & $\mathbf{n}(\%)$ & n $(\%)$ \\
\hline \multicolumn{4}{|l|}{ Status Gizi } \\
\hline Underweight & $4(33,3 \%)$ & $8(66,7 \%)$ & $12(100 \%)$ \\
\hline Normal & $23(52,3 \%)$ & $21(47,7 \%)$ & $44(100 \%)$ \\
\hline Overweight & $3(75 \%)$ & $1(25 \%)$ & $4(100 \%)$ \\
\hline Obes I & $2(100 \%)$ & $0(0 \%)$ & $2(100 \%)$ \\
\hline \multicolumn{4}{|l|}{ Persentase Lemak Tubuh } \\
\hline Underfat & $2(40 \%)$ & $3(60 \%)$ & $5(100 \%)$ \\
\hline Normal & $27(50 \%)$ & $27(50 \%)$ & $54(100 \%)$ \\
\hline Overfat & $3(100 \%)$ & $0(0 \%)$ & $3(100 \%)$ \\
\hline \multicolumn{4}{|l|}{ Aktivitas Fisik } \\
\hline Sedang & $0(0 \%)$ & $5(100 \%)$ & $5(100 \%)$ \\
\hline Berat & $32(56,1 \%)$ & $25(43,9 \%)$ & $57(100 \%)$ \\
\hline \multicolumn{4}{|l|}{ Asupan Energi } \\
\hline Defisit tingkat berat & $13(100 \%)$ & $0(0 \%)$ & $13(100 \%)$ \\
\hline Defisit tingkat sedang & $17(58,6 \%)$ & $12(41,4 \%)$ & $29(100 \%)$ \\
\hline Defisit tingkat ringan & $2(10,5 \%)$ & $17(89,5 \%)$ & $19(100 \%)$ \\
\hline Normal & $0(0 \%)$ & $1(100 \%)$ & $1(100 \%)$ \\
\hline \multicolumn{4}{|l|}{ Asupan Protein } \\
\hline Defisit tingkat berat & $2(40 \%)$ & $3(60 \%)$ & $5(100 \%)$ \\
\hline Defisit tingkat sedang & $4(33,3 \%)$ & $8(66,7 \%)$ & $12(100 \%)$ \\
\hline Defisit tingkat ringan & $10(50 \%)$ & $10(50 \%)$ & $20(100 \%)$ \\
\hline Normal & $16(64 \%)$ & $9(36 \%)$ & $25(100 \%)$ \\
\hline \multicolumn{4}{|l|}{ Asupan Lemak } \\
\hline Defisit tingkat berat & $18(78,3 \%)$ & $5(21,7 \%)$ & $23(100 \%)$ \\
\hline Defisit tingkat sedang & $11(73,3 \%)$ & $4(26,7 \%)$ & $15(100 \%)$ \\
\hline Defisit tingkat ringan & $1(6,7 \%)$ & $14(93,3 \%)$ & $15(100 \%)$ \\
\hline Normal & $2(22,2 \%)$ & $7(77,8 \%)$ & $9(100 \%)$ \\
\hline \multicolumn{4}{|l|}{ Asupan Karbohidrat } \\
\hline Defisit tingkat berat & $6(100 \%)$ & $0(0 \%)$ & $6(100 \%)$ \\
\hline Defisit tingkat sedang & $18(90 \%)$ & $2(10 \%)$ & $20(100 \%)$ \\
\hline Defisit tingkat ringan & $8(25 \%)$ & $24(75 \%)$ & $32(100 \%)$ \\
\hline Normal & $0(0 \%)$ & $4(100 \%)$ & $4(100 \%)$ \\
\hline
\end{tabular}


Hubungan Asupan Energi, Asupan Protein, Asupan Lemak, Asupan Karbohidrat, Aktivitas Fisik, dan Persentase Lemak Tubuh dengan Gangguan Siklus Menstruasi

Berdasarkan data yang disajikan dalam Tabel 6, didapatkan hasil uji analisis statistik yang menunjukkan adanya hubungan yang signifikan antara asupan energi, asupan lemak, asupan karbohidrat, dan aktivitas fisik dengan gangguan siklus menstruasi $(\mathrm{p}<0,05)$ serta tidak adanya hubungan yang signifikan antara asupan protein dan persentase lemak tubuh dengan gangguan siklus menstruasi $(\mathrm{p}>0,05)$.

Tabel 6. Analisis Bivariat Hubungan Asupan Energi, Asupan Protein, Asupan Lemak, Asupan Karbohidrat, Aktivitas Fisik, dan Persentase Lemak Tubuh dengan Gangguan Siklus Menstruasi

\begin{tabular}{|c|c|c|c|c|}
\hline \multirow[t]{3}{*}{ Variabel } & \multicolumn{2}{|c|}{ Gangguan siklus menstruasi } & \multicolumn{2}{|c|}{ Analisis bivariat } \\
\hline & \multirow{2}{*}{$\begin{array}{c}\text { Ya } \\
\mathbf{n}(\%)\end{array}$} & \multirow{2}{*}{$\begin{array}{l}\text { Tidak } \\
\text { n }(\%)\end{array}$} & \multirow[b]{2}{*}{$p$} & \multirow[b]{2}{*}{$\mathbf{R R}$} \\
\hline & & & & \\
\hline \multicolumn{5}{|l|}{ Asupan energy } \\
\hline Defisit tingkat berat + sedang & $30(71,4 \%)$ & $12(28,6 \%)$ & \multirow{3}{*}{$0,000^{*}$} & \multirow{3}{*}{7,14} \\
\hline Defisit tingkat ringan + normal & $2(10,0 \%)$ & $18(90,0 \%)$ & & \\
\hline Asupan protein & & & & \\
\hline Defisit tingkat berat + sedang & $6(35,3 \%)$ & $11(64,7 \%)$ & \multirow{2}{*}{$0,195^{*}$} & \multirow{2}{*}{0,61} \\
\hline Defisit tingkat ringan + normal & $26(57,8 \%)$ & $19(42,2 \%)$ & & \\
\hline $\begin{array}{l}\text { Asupan lemak } \\
\text { Defisit tingkat berat + sedang }\end{array}$ & $29(76,3 \%)$ & $9(23.7 \%)$ & \multirow{3}{*}{$0,000^{*}$} & \multirow{3}{*}{6,10} \\
\hline Defisit tingkat ringan + normal & $3(12,5 \%)$ & $21(87,5 \%)$ & & \\
\hline Asupan karbohidrat & & & & \\
\hline Defisit tingkat berat + sedang & $24(92,3 \%)$ & $2(7,7 \%)$ & \multirow{2}{*}{$0,000 *$} & \multirow{2}{*}{4,15} \\
\hline Defisit tingkat ringan + normal & $8(22,3 \%)$ & $28(77,8 \%)$ & & \\
\hline Sedang & $0(0 \%)$ & $5(100 \%)$ & \multirow{3}{*}{$0,022^{\mathrm{a}}$} & \multirow{2}{*}{2,28} \\
\hline Berat & $32(56,1 \%)$ & $25(43,9 \%)$ & & \\
\hline \multicolumn{4}{|l|}{ Persentase lemak tubuh } & \\
\hline Underfat + overfat & $5(62,5 \%)$ & $3(37,5 \%)$ & \multirow{2}{*}{$0,709^{\mathrm{a}}$} & \multirow{2}{*}{1,25} \\
\hline Normal & $27(50,0 \%)$ & $27(50,0 \%)$ & & \\
\hline
\end{tabular}

\section{PEMBAHASAN}

\section{Karakteristik Subjek}

Penelitian ini dilakukan pada subjek mahasiswi tari dengan rentang usia 19-22 tahun. Rentang usia tersebut termasuk dalam masa dewasa muda yang merupakan salah satu tahap dari siklus kehidupan dengan rentang usia 19-40 tahun. Pada tahap ini terjadi proses pematangan pertumbuhan dan perkembangan baik secara fisik maupun psikologis. Pematangan pertumbuhan dan perkembangan secara fisik meliputi berbagai organ salah satunya adalah organ reproduksi. Kesehatan reproduksi pada tahap ini sangatlah penting karena berkaitan erat dengan tingkat fertilitas. ${ }^{19}$ Hasil penelitian ini menunjukkan bahwa dari total 62 subjek sebanyak 32 subjek $(51,6 \%)$ mengalami gangguan siklus menstruasi. Hasil penelitian ini sejalan dengan penelitian yang telah dilakukan sebelumnya di Iran, bahwa kejadian gangguan siklus menstruasi pada wanita usia reproduktif paling tinggi terjadi pada wanita berusia 20-25 tahun dan hanya $39,8 \%$ subjek yang memiliki siklus menstruasi normal. ${ }^{19}$
Berdasarkan IMT, pada penelitian ini $33,3 \%$ subjek dengan status gizi underweight mengalami gangguan siklus menstruasi. Sebanyak $75 \%$ subjek dengan overweight dan $100 \%$ subjek dengan obesitas juga mengalami gangguan siklus menstruasi. Wanita dengan berat badan kurang dan berat badan lebih berisiko tinggi terhadap ovulasi infertil dan ketidakteraturan siklus menstruasi berkaitan dengan adanya kelainan pada pengeluaran hormon. ${ }^{20}$

Rendahnya berat badan berkaitan dengan gangguan fungsi hipotalamus yang mengarah pada penekanan sekresi GnRH. Kondisi ini mempengaruhi penurunan sekresi dan kadar hormon gonadotropin dalam serum dan urin. Selain itu juga terjadi perubahan kadar hormon steroid yang ditandai dengan meningkatnya kadar testosteron serum. Hal tersebut mengakibatkan siklus menstruasi lebih panjang. ${ }^{21,22}$

Kondisi overweight dan obesitas berkaitan dengan penumpukan lemak dalam jaringan adiposa berkorelasi positif dengan peningkatan kadar leptin. Leptin akan memicu pengeluaran $\mathrm{GnRH}$ 
yang mempengaruhi FSH dan LH dalam merangsang pematangan folikel dan pembentukan hormon estrogen..$^{21,23}$ Hal tersebut memicu tingginya kadar hormon estrogen sehingga memberikan umpan balik negatif terhadap sekresi GnRH. Selain kelebihan estrogen, pada wanita dengan berat badan berlebih juga kelebihan androgen yang mengakibatkan terjadi gangguan fungsi ovarium dan kelainan siklus mentruasi. ${ }^{24}$

\section{Hubungan Asupan Energi dengan Gangguan} Siklus Menstruasi

Data asupan energi yang diperoleh melalui wawancara langsung dengan menggunakan FFQ menunjukkan sebanyak 13 subjek $(21,0 \%)$ tergolong defisit tingkat berat, 29 subjek $(46,8 \%)$ tergolong defisit tingkat sedang, 19 subjek $(30,6 \%)$ tergolong defisit tingkat ringan, dan hanya terdapat 1 subjek $(1,6 \%)$ yang memiliki asupan energi cukup. Rerata asupan energi subjek yaitu $75,05 \pm 6,33 \%$ dari AKG. Hal ini sama dengan penelitian yang dilakukan oleh Frusztajer bahwa $70 \%$ dari penari memiliki rata-rata tingkat asupan energi sehari-hari di bawah $85 \%$ Angka Kecukupan Gizi. ${ }^{5}$ Hampir seluruh subjek yang memiliki asupan energi kurang disebabkan oleh seringnya meninggalkan kebiasan sarapan dan lebih memilih mengganti sarapan hanya dengan segelas minuman manis atau susu. Asupan energi yang kurang juga disebabkan sedikitnya porsi saat makan terutama nasi. Kurangnya frekuensi makan dan lebih senang mengkonsumsi camilan dengan kadar kalori yang lebih rendah seperti snack ringan, jus buah maupun buah segar sebagai pengganti nasi juga merupakan penyebab kurangnya asupan energi.

Berdasarkan kategori kecukupan asupan energi, subjek dengan defisit asupan energi tingkat berat $(100 \%)$ mengalami gangguan siklus menstruasi. Sebagian besar subjek dengan defisit asupan energi tingkat sedang $(58,6 \%)$ juga mengalami gangguan siklus menstruasi. Subjek dengan asupan energi normal tidak mengalami gangguan siklus menstruasi.

Analisis bivariat menunjukkan adanya hubungan yang signifikan antara asupan energi dengan gangguan siklus menstruasi $(\mathrm{p}=0,000)$. Subjek dengan asupan energi defisit tingkat berat dan sedang memiliki risiko 7,14 kali lebih besar untuk mengalami gangguan siklus menstruasi dibandingkan subjek dengan asupan energi defisit tingkat ringan dan normal. Kekurangan asupan energi mengakibatkan penurunan kadar hormon estrogen yang merupakan hormon pengatur siklus menstruasi. Rendahnya kadar hormon estrogen mengakibatkan terjadinya penurunan fungsi reproduksi dan gangguan siklus menstruasi. ${ }^{7}$

\section{Hubungan Asupan Lemak dengan Gangguan} Siklus Menstruasi

Sebanyak 78,3\% subjek dengan asupan lemak defisit tingkat berat mengalami gangguan siklus menstruasi. Hanya terdapat $22,2 \%$ subjek dengan asupan lemak normal yang mengalami gangguan siklus menstruasi. Hasil analisis bivariat menunjukkan adanya hubungan yang signifikan antara asupan lemak dengan gangguan siklus menstruasi $(\mathrm{p}=0,000)$. Subjek dengan asupan lemak defisit tingkat berat dan sedang memiliki risiko 6,1 kali lebih besar untuk mengalami gangguan siklus menstruasi dibandingkan subjek dengan asupan lemak defisit tingkat ringan dan normal.

Lemak dalam asupan makan menyumbang energi lebih besar dibanding dengan protein dan karbohidrat yaitu sebesar 9 Kkal. Diit rendah lemak akan menyebabkan 3 efek utama yaitu siklus menstruasi memanjang dan meningkat ratarata 1,3 hari, lamanya waktu menstruasi meningkat rata-rata 0,5 hari, dan fase folikuler meningkat rata-rata 0,9 hari. ${ }^{22,25}$ Pada wanita yang kekurangan asupan lemak, kadar hormon steroid mengalami peningkatan. Semua hormon seks merupakan steroid yang diubah dari molekul prekusor melalui kolesterol sampai bentuk akhirnya. Kolesterol sebagai prekusor steroid disimpan dalam jumlah banyak di sel-sel teka. Pematangan folikel yang mengakibatkan meningkatnya biosintesa steroid dalam folikel diatur oleh GnRH. Progesteron adalah suatu steroid aktif dan juga berfungsi sebagai prekursor untuk tahap-tahap selanjutnya. Di bawah rangsangan $\mathrm{LH}$, steroid oleh jaringan perifer diubah menjadi senyawa aktif secara androgenis mengakibatkan peningkatan kadar testosteron serum dan penurunan ekskresi 17-ketosteroid dalam urin sehingga berdampak pada perubahan siklus ovulasi dan terganggunya siklus menstruasi. $^{22,25}$

\section{Hubungan Asupan Karbohidrat dengan Gangguan Siklus Menstruasi}

Karbohidrat merupakan sumber energi utama dalam otot. Setiap asupan makan penari harus mengandung $55-60 \%$ karbohidrat. Saat latihan dengan kadar yang tinggi jumlah karbohidrat perlu ditingkatkan menjadi $65 \% .{ }^{26}$ Hasil penelitian ini menunjukkan hanya 6,5\% subjek yang memiliki asupan karbohidrat normal dan sebagian besar subjek $(51,6 \%)$ memiliki asupan karbohidrat defisit tingkat ringan.

Subjek dengan asupan karbohidrat defisit tingkat berat (100\%) dan 90\% subjek dengan 
asupan karbohidrat defisit tingkat sedang mengalami gangguan siklus menstruasi. Subjek dengan asupan karbohidrat normal tidak mengalami gangguan siklus menstruasi. Analisis bivariat menunjukkan adanya hubungan yang signifikan antara asupan karbohidrat dengan gangguan siklus menstruasi $(\mathrm{p}=0,000)$. Subjek dengan asupan karbohidrat defisit tingkat berat dan sedang memiliki risiko 4,15 kali lebih besar untuk mengalami gangguan siklus menstruasi dibandingkan subjek dengan asupan karbohidrat defisit tingkat ringan dan normal.

Karbohidrat merupakan sumber peningkatan asupan kalori selama fase luteal, sehingga apabila asupan karbohidrat terpenuhi maka tidak akan terjadi pemendekan fase luteal. ${ }^{22,25}$ Karbohidrat memegang peranan penting dalam pengaturan glukosa darah. Konsentrasi glukosa darah yang rendah dapat mengakibatkan tubuh memproduksi hormon adrenalin. Adrenalin dapat menghentikan efektifitas progesteron yang berfungsi menekan aktivitas kerja hormon estrogen, sehingga siklus menstruasi tidak menjadi lebih panjang. ${ }^{27}$

\section{Hubungan Aktivitas Fisik dengan Gangguan Siklus Menstruasi}

Menari sebanding dengan olahraga yang tergolong dalam aktivitas fisik yang berat dilihat dari segi fisik, ketangkasan, dan psikologis. ${ }^{1}$ Menari juga merupakan sebuah latihan yang mensubstitusi aspek atletik dengan komponen artistik dan estetik. ${ }^{28}$ Hal ini dibuktikan dengan hasil penelitian yang menyatakan sebagian besar aktivitas fisik subjek dalam penelitian ini tergolong berat dengan rerata $6236,54 \pm 2577,19$ METmenit/minggu.

Subjek dengan aktivitas fisik sedang pada penelitian ini tidak mengalami gangguan siklus menstruasi. Sebanyak 51,6\% subjek dengan aktivitas fisik berat mengalami gangguan siklus menstruasi. Analisis bivariat menunjukkan adanya hubungan yang signifikan antara aktivitas fisik dengan gangguan siklus menstruasi $(\mathrm{p}=0,022)$. Subjek dengan aktivitas fisik sedang memiliki risiko untuk mengalami siklus menstruasi normal sebesar 2,28 kali lebih besar dibandingkan subjek dengan aktivitas fisik berat.

Hasil penelitian ini sesuai dengan penelitian sebelumnya yang menyebutkan bahwa kelainan sistem reproduksi termasuk gangguan menstruasi dialami oleh 6-79\% perempuan yang terlibat dalam kegiatan dengan aktivitas berat salah satunya adalah profesi sebagai penari. ${ }^{13}$ Sifat dan tingkat keparahan gejala gangguan siklus menstruasi tergantung pada beberapa hal seperti jenis latihan, intensitas, dan lamanya latihan serta laju perkembangan program pelatihan. Aktivitas fisik berlebihan dapat menyebabkan terjadinya disfungsi hipotalamus yang menyebabkan gangguan pada sekresi GnRH. Hal tersebut menyebabkan menarche yang tertunda dan gangguan siklus mentruasi dengan perubahan metabolisme steroid yang mempengaruhi release atau penglepasan gonadotrophin. ${ }^{7}$

Meningkatnya aktivitas fisik juga berhubungan positif dengan panjang fase folikuler. Penelitian yang dilakukan di California menyebutkan wanita berusia kurang dari 35 tahun dengan aktivitas fisik $>4$ jam per minggu secara signifikan memperpanjang fase folikuler. ${ }^{29}$ Penelitian yang dilakukan oleh Patras University Medical School juga menyatakan gangguan siklus menstruasi dan tertundanya menarche dialami oleh remaja dan wanita dewasa yang melakukan pelatihan secara intensif selama 15 jam atau lebih setiap minggunya. ${ }^{13}$ Intensitas aktivitas fisik yang terlalu tinggi sehingga tidak mampu dikompensasi oleh tubuh dapat menyebabkan gangguan endokrin dalam tubuh salah satunya ketidakteraturan siklus menstruasi. $^{30}$

Hubungan Asupan Protein dengan Gangguan Siklus Menstruasi

Protein sangat dibutuhkan untuk memperbaiki kerusakan sel-sel tubuh dan memperbaiki pemecahan serat otot yang mengalami cidera akibat latihan. Protein juga digunakan sebagai cadangan energi dan mensistesis enzim-enzim yang dibutuhkan selama metabolisme. ${ }^{26}$ Asupan protein berhubungan dengan panjangnya fase folikuler. Asupan protein hewani yang berlebih akan memperpanjang fase folikuler. Hal ini dibuktikan pada penelitian yang dilakukan untuk mengetahui pengaruh diit vegetarian terhadap hormon seks, didapatkan 9 orang vegetarian diberi diit yang mengandung daging mengalami pemanjangan fase folikuler rata-rata 4,2 hari, peningkatan FSH, dan penurunan estradiol $\left(\mathrm{E}_{2}\right)$ secara signifikan. Sebaliknya 16 orang dengan diit biasa yang beralih ke diit dengan kurangnya konsumsi daging selama dua bulan mengalami penurunan puncak $\mathrm{LH}$, peningkatan kadar LH, dan pemendekan fase folikuler rata-rata 3,8 hari. ${ }^{22,25}$

Hasil analisis bivariat menunjukkan tidak adanya hubungan yang signifikan antara asupan protein dengan gangguan siklus menstruasi $(p=0,195)$. Subjek dengan asupan protein defisit tingkat berat dan sedang memiliki risiko 0,61 kali lebih besar untuk mengalami gangguan siklus 
menstruasi dibandingkan subjek dengan asupan protein defisit tingkat ringan dan normal.

Hasil yang didapatkan dalam penelitian ini bertentangan dengan teori dan penelitian sebelumnya. Hal ini dimungkinkan karena banyaknya subjek yang memiliki asupan protein normal $(64 \%)$ tetapi mengalami gangguan siklus menstruasi sehingga menjadi perancu dalam penelitian ini. Hal tersebut dapat terjadi dikarenakan subjek lebih banyak mengkonsumsi protein hewani dibanding protein nabati. Penelitian di Boston membuktikan tingginya konsumsi protein hewani meningkatkan risiko terjadinya infertilitas akibat anovulasi dan konsumsi protein nabati dapat mengurangi risiko terjadinya infertilitas. ${ }^{31}$ Selain itu terjadinya gangguan siklus menstruasi pada subjek dengan asupan protein normal juga disebabkan oleh aktivitas fisik yang berat $(100 \%)$ dengan defisit tingkat sedang asupan energi (75\%), asupan lemak (62,5\%), dan asupan karbohidrat (56\%).

\section{Hubungan Persentase Lemak Tubuh dengan Gangguan Siklus Menstruasi}

Sebagian besar subjek $(87,1 \%)$ memiliki persentase lemak tubuh dengan kategori normal. Hanya terdapat $8,1 \%$ subjek yang memiliki persentase lemak tubuh dengan kategori underfat dan 4,8\% subjek dengan kategori overfat. Hal ini menunjukkan penari pada penelitian ini tidak mengutamakan bentuk kerampingan tubuh seperti pada penari balet yang memiliki persentase lemak tubuh rendah. ${ }^{4}$

Lemak tubuh sangat berpengaruh pada tingkat sekresi dan keseimbangan hormon reproduksi yang mengatur menstruasi dalam tubuh karena jaringan adiposa berperan dalam membentuk, mengkonversi, dan menyimpan hormon-hormon reproduksi yang berperan dalam mengatur siklus menstruasi. Rendahnya kadar lemak tubuh dapat mengakibatkan rendahnya kadar estrogen yang berhubungan dengan kejadian infertilitas. Sedangkan jumlah lemak tubuh yang meningkat akan meningkatkan jumlah estrogen dalam darah sehingga mengakibatkan siklus menstruasi menjadi lebih panjang. Kelebihan lemak tubuh juga dapat mengakibatkan hiperplasi pembuluh darah yaitu terdesaknya pembuluh darah oleh jaringan lemak. Apabila hal ini terjadi pada organ reproduksi wanita maka darah yang seharusnya mengalir pada proses menstruasi terganggu, mengakibatkan menstruasi lebih lama dan siklus menstruasi yang tidak teratur. ${ }^{26,32}$

Hasil analisis bivariat menunjukkan tidak adanya hubungan yang signifikan antara persentase lemak tubuh dengan gangguan siklus menstruasi
( $>>0,05)$. Akan tetapi didapatkan besar nilai risiko kejadian gangguan menstruasi 1,25 kali lebih besar pada subjek underfat dan overfat dibandingkan subjek dengan persentase lemak tubuh normal. Hasil penelitian ini sama dengan penelitian di Kanada yang menyatakan tidak ada pengaruh yang signifikan antara persentase lemak tubuh dengan gangguan siklus menstruasi pada atlet pesenam. ${ }^{33}$ Namun, hasil penelitian ini bertentangan dengan penelitian yang dilakukan oleh Frisch et al, yang menemukan tingginya insiden amenore primer, amenore sekunder, siklus menstruasi tidak teratur dan tertundanya menarche berhubungan dengan tingkat kerampingan bentuk tubuh pada 89 penari balet. ${ }^{4}$ Sabbour dan $E l$ juga menemukan penari dengan gangguan menstruasi oligomenore memiliki persentase lemak tubuh lebih rendah dibandingkan penari dengan siklus menstruasi normal. ${ }^{11}$

Ketidaksesuaian hasil penelitian ini dengan teori dan penelitian sebelumnya dimungkinkan karena banyaknya subjek dengan persentase lemak tubuh normal $(50 \%)$ tetapi mengalami gangguan siklus menstruasi sehingga menjadi perancu dalam penelitian ini. Hal ini dapat terjadi dikarenakan dalam penelitian ini persentase lemak tubuh bukan menjadi satu-satunya penyebab terjadinya gangguan siklus menstruasi. Aktivitas fisik yang berat $(100 \%)$ dengan defisit tingkat berat asupan lemak (62\%) serta defisit tingkat sedang asupan energi (55\%) dan karbohidrat (62\%) juga menjadi faktor yang mempengaruhi terjadinya gangguan siklus menstruasi pada subjek dengan persentase lemak tubuh normal.

\section{SIMPULAN}

Sebanyak $51,6 \%$ penari pada penelitian ini mengalami gangguan siklus menstruasi. Asupan energi pada 46,8\% subjek tergolong defisit tingkat sedang. Asupan protein pada $32,3 \%$ subjek dan asupan karbohidrat pada $51,6 \%$ subjek tergolong defisit tingkat ringan. Asupan lemak pada 37,1\% subjek tergolong defisit tingkat berat. Sebagian besar subjek dalam penelitian ini memilki aktivitas fisik yang berat $(91,9 \%)$ dan persentase lemak tubuh yang normal $(87,1 \%)$.

Terdapat hubungan antara asupan energi, lemak, karbohidrat, dan aktivitas fisik dengan gangguan siklus menstruasi $(p<0,05)$. Tidak terdapat hubungan antara asupan protein dan persentase lemak tubuh dengan gangguan siklus menstruasi $(p>0,05)$. 


\section{SARAN}

Penari dianjurkan untuk meningkatkan asupan zat gizi meliputi energi, protein, lemak, dan karbohidrat yang disesuaikan dengan pengeluaran energi melalui aktivitas fisik sehingga dapat mengurangi kejadian gangguan siklus menstruasi. Penelitian lebih lanjut tentang gangguan siklus menstruasi pada penari disarankan untuk dilakukannya uji laboratorium terkait hormon yang mempengaruhi siklus menstruasi dan hubungan stress dengan gangguan siklus menstruasi untuk memperoleh hipotesis dan hasil yang lebih kuat.

\section{DAFTAR PUSTAKA}

1. Maffulli N, Chan KM, Macdonald R, Malina RM, Parker T. Sport Medicine for Specific Ages and Abilities. In: Wong MWN, To WWK, Chan KM. dance Medicine. Available from URL: https://www.us.elsevierhealth.com.

2. Koutedakis Y, Jamurtas A. The Dancer as a Performing Athlete. Sport Med 2004: 34 (10): 651-661.

3. Gibbs R. Guidelines for Professional Dance Companies on Healthy Nutrition. USA: Taskforce on Dancer Health 2011.p.3-17.

4. Adno J. Menstrual Disorders in the Active, Underweight Female. Women and Sport 2012.p.2-6.

5. Burckhardt P, Wynn E, Krieg MA, Bagutti C, Fouzi M. The Effects of Nutrition, Puberty and Dancing on Bone Density in Adolescent Ballet Dancers. Journal of Dance Medicine and Science 2011; 10:2.p.51-60.

6. Amelia IN, Syauqy A. Hubungan Antara Asupan Energi dan Aktivitas Fisik dengan Persen Lemak Tubuh pada Wanita Peserta Senam Aerobik. Journal of Nutrition College 2014; 3:1.p.200-205.

7. Asmarani R. Pengaruh Olahraga terhadap Siklus Haid Atlit [skripsi]. Semarang: Universitas Diponegoro; 2010.

8. Saputri GARR, Dieny FF. Female Athlete Triad pada Atlet Putri di Pusat Pendidikan Latihan (PUSDIKLAT) Ragunan Jakarta. Journal of Nutrition College 2012; 1:1.p.405413.

9. Gudmundsdottir SL, Flanders WD, Augestad LB. A Longitudinal Study of Physical Activity and Menstrual Cycle Characteristic in Healthy Norwegian Women-The Nord-Trondelag Health Study. Norsk Epidemiologi 2011; 20(2):163-171.

10. Yuliana BN, Dieny FF. Ketidakpuasan Terhadap Citra Tubuh dan Kejadian Female Athlete Triad (FAT) pada Remaja Putri.
Journal of Nutrition College 2013; 2:4.p.705712.

11. Wiknjosastro H, Saifuddin AB, Rachimhadhi T, editors. Ilmu Kandungan. Ed 2, Cet ke 4, Jakarta: Yayasan Bina Pustaka Sarwono Prawirohardjo; 2005.p.103-127, 204-229.

12. Sabbour A, El-Deeb A. Evaluation of Menstrual Status, Bone Mineral Density and Body Composition in Egyptian Ballet Dancer. Bull.Fac.Ph.Th.Cairo Univ 2011; 16:2.p.61-69.

13. Nattiv A, Loucks AB, Manore MM, Sanbom $\mathrm{CF}$, Borgen JS, Warren MP. The Female Athlete Triad. American College of Sports Medicine 2007; 1867-1882.

14. Roupas ND, Georgopoulos NA. Menstrual Function in Sport. Hormones 2011; 10(2): 104-116.

15. Rindu DM, Faisal A, Dadang S. Kaitan antara Status Gizi, Perkembangan Kognitif, dan Perkembangan Motorik pada Anak Usia Prasekolah. Penelitian Gizi dan Makanan 2013; 36(1): 62-72.

16. IPAQ Research Committee. Guidelines for Data Processing and Analysis of the International Physical Activity Questionnaire (IPAQ) - Short and Long Form. [serial online] 2005. Available from URL: HYPERLINK http://www.ipaq.ki.se

17. National Institutes of Health and World Health Organization. Body Fat Ranges of Standart Adults. 2000. Available from URL: http://obesityresearch.nih.gov

18. Manuaba. Buku Ajar Ginekologi. Jakarta: EGC; 2010.p.25-48.

19. Gharravi AM. Menstrual Cycle Patterns of College Students in Gorgan Northeast of Iran: Identify Its Association with Sociodemographic Factors. Erciyes Medical Journal 2009; 31(4):331-338

20. Rowland AS, Baird DD, Long S, Wegienka G, Harlow SD, Alavanja $\mathrm{M}$, et al. Influence of Medical Conditions and Lifestyle Factors on The Menstrual Cycle. Epidemiologi 2002; 13:668-674.

21. Pratiwi A. Hubungan Status Gizi dengan Keteraturan Siklus Menstruasi Siswi SMA Negeri 1 Mojolaban [skripsi]. Surakarta: Universitas Sebelas Maret; 2011.

22. Paath EF, Rumdasih Y, Heryati. Gizi dalam Kesehatan Reproduksi. Jakarta: EGC; 2005.p.67-72.

23. Setijowati N, Eriza F, Rosy H. Hubungan Asupan Lemak dengan Kejadian Menarche pada Remaja Putri. Malang: Universitas Brawijaya; 2013.p.1-6. 
24. Adnyani, Gunahariati NN, Triyani NGA. Hubungan Status Gizi dengan Siklus Menstruasi pada Remaja Putri Kelas X di SMA PGRI 4 Denpasar. Denpasar: Universitas Udayana; 2013.

25. Marmi. Gizi dalam Kesehatan Reproduksi. Yogyakarta: Pustaka Pelajar; 2013.p.399-400.

26. Clarkson P. Nutrition Fact Sheet: Fueling The Dancer. International Association For Dance Medicine Science. Available from: URL: $\mathrm{http}: / / \mathrm{www}$.dancemedicine.org.

27. Mazarina D. Hubungan Kebiasaan makan dengan Kejadian Sindrom Pramenstruasi pada Remaja Putri. Teknologi dan Kejuruan 2009; 32(2): 197-208

28. Yannakoulia M, Keramopoulos A, Tsakalakos N, Matalas AL. Body Composition in Dancer: The Bioelectrical Impedance Method. American College of Sports Medicine 2000; 288-234.

29. Liu Y, Gold EB, Lasley BL, Johnson WO. Factors Affecting Menstrual Cycle Characteristic. Am J Epidemiol 2004; 160:2.p.131-140.

30. Arovah NI. Female Ethlete Triad pada Atlet Wanita (Diagnosis, Pencegaha, dan Penatalaksanaan). Yogyakarta: Universita Negeri Yogyakarta; 2010.p.1-12.

31. Jorge EC, Janet WR, Bernard AR, walter CW. Protein Intake and Ovulatory Infertility. AM J Obsetet Gynecol 2008; 198(2):210e1-210e7.

32. Rakhmawati A, Dieny FF. Hubungan Obesitas dengan Kejadian Gangguan Siklus Menstruasi pada Wanita Dewasa Muda. Journal Nutrition College 2013; 2:1.p.214-222.

33. Klentrou P, Plyley M. Onset of Puberty, Menstrual Frequency, and Body Fat in Elite Rhythmic Gymnasts Compared with Normal Controls. Canada: Br J Sport Med. 2003; 37:490-494 